Forschungszentrum für Umweltpolitik

Environmental Policy Research Centre

\title{
Europeanization of Energy and Climate Policy:
}

New trends and their implications for the German energy transition process

Kerstin Tews

FFU-Report 03-2014

Forschungszentrum für Umweltpolitik Freie Universität Berlin

Fachbereich Politik- und Sozialwissenschaften Otto-Suhr-Institut für Politikwissenschaft 


\title{
Publisher
}

Freie Universität Berlin

Forschungszentrum für Umweltpolitik

Ihnestraße 22

14195 Berlin

Web: www.fu-berlin.de/ffu

ISSN 1612-3026

FFU-Rep 03-2014 (September)

\section{Europeanization of Energy and Climate Policy: New trends and their implications for the German energy transition process}

This paper is a result of ongoing research in the framework of the Helmholtz-Alliance "Energy Trans".

I would particularly like to thank my colleagues Dr. Sibyl Steuwer and Robert Brand for providing helpful comments on an initial draft of this paper.

\author{
Author \\ Dr. Kerstin Tews: \\ kerstin.tews@fu-berlin.de
}

The Environmental Policy Research Centre (FFU) has been publishing its FFU reports since 1993. FFU reports encompass both academic papers and policy-oriented studies. All FFUreports are either peer-reviewed internally or have been reviewed by other project partners and/ or the commissioning client. The views expressed are solely the authors' and do not necessarily reflect those of the FFU. 
Abstract

In this paper I discuss very recent developments in the post-2020 climate and energy policy framework of the European Union as well as their implications for the German energy transition process. In a first step, I analyze how the need for the planned modifications of the European strategy is framed. I argue that the European Commission obviously sparked off a new round in tackling a longstanding governance dilemma between European market integration and regulatory diversity among Member States regarding energy and environmental issues.

In a second step, I take a closer look at the implications of these changes at the European level for the German energy transition pathway. I argue that supranational pressure to adapt national energy policies to internal market rules coincides with the dominant domestic framing of the need for market integration of renewable energies. This interplay of problem framings, on the one hand, and the discretionary power of the European Commission to control competition rules, on the other, explains the very recent instrumental shift in the German national support scheme for renewable energies.

Subsequently, I debate various governance options for dealing with the implications of the proposed new European approach to energy and climate policy, both against the backdrop of the particular German way of energy transition as well as against the backdrop of general transition challenges. 


\section{Contents}

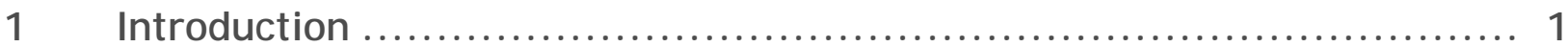

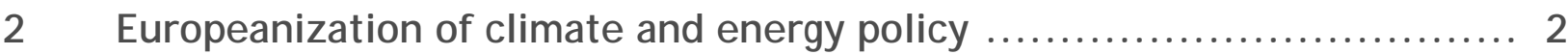

2.1 The degree of vertical integration in the current climate and energy policy framework 2009-2020. A brief overview ....

2.2 Europe at a crossroad? The shaping of the post-2020 energy and climate policy framework through the prism of single market integration............. 4

The break with the three-pillar approach in the target architecture ........... 5

Flexibility of Member States versus a strong European governance framework: An inherent governance dilemma within the EU ................ 7

Supranational pressure to force regulatory harmonization in RES support



3 Implications for the German energy transition process and governance options for a low carbon energy system transition ............................ 14

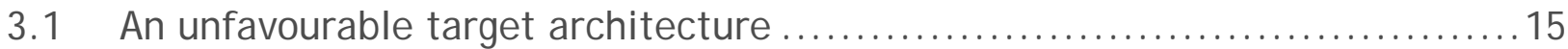

A possible complementarity of governance options: leadership in multilateral negotiations, bilateral cooperation and horizontal processes of policy diffusion

3.2 A hasty government's adaptation to supranational pressure: the remaining governance options regarding instrument choice for RES support ............. 20

A careful instrument design by including normative elements .................21





List of figures

Figure 1: $\quad$ Main findings of the impact assessment of policy options regarding target architecture

Figure 2: The inherent governance dilemma in European RES-policy and the new attempt to define adequate policy levels and instrument choices....... 10 


\section{Introduction}

In March 2013 the European Commission (EC) started the debate on and related activities for the new post-2020 energy and climate policy framework. It is becoming obvious that the Commission envisions significant changes in the framework. On the one hand, its main amendments concern the abolishment of the three-pillar approach in the target architecture pursued so far. On the other hand, we can observe a reinforced supranational pressure for energy policy coordination, precisely to harmonize national support schemes for renewable energies.

In the first section of this paper, I will analyse these modifications in the European framework in detail. I will show that the planned modification in the target architecture aim at increasing the flexibility of Member States to deliver GHG-reduction. Seemingly contradictory at first glance, however, are the Commission's intensified efforts to finally come forward with a regulatory harmonization of support schemes for renewable energies, which, in fact, restricts national flexibility. I will argue that both of these modifications are recommended not for their effectiveness in achieving climate or environmental objectives, but for their alignment with core beliefs within EU supranational institutions regarding cost-efficiency and internal market compatibility of targets, policies and measures. The need for greater energy policy coordination is viewed by the EC solely through the prism of single market integration. This perspective implies policy choices regarding the adequate policy level to act within the European multi-level-system and the appropriate policy instruments.

In the next section, I will analyse the implications of these changes in the energy and climate policy framework at European level for the German energy transition pathway. In Germany, there has long been a tendency to limit discussions related to the energy transition to the need for greater political coordination within the German federal system. Only recently has the political relevance of European policies to the German energy transition been given much greater political attention. This has been enforced not only by the conspicuous signals given from actors at the European level. More significantly, the supranational pressure to adapt national policies to internal market rules coincides with the dominant domestic framing of the need for market integration of renewable energies. This interplay of problem framings, on the one hand, and the discretionary power of the European Commission to control competition rules, on the other, explains the very recent instrumental shift in the German national support scheme for renewable energies.

In a subsequent step, I discuss various governance options for dealing with the implications of the proposed new European approach to energy and climate policy, both against the background of the particular German way of energy transition as well as against the background of general transition challenges. As a transition process is a complex socio-technical change, which requires destabilizing lock-in mechanisms of the existing system, shifts in behavioural patterns of consumers and producers, as well as technological, political and 
social innovations (cf. Geels 2010), I will argue for widening of the perspective from onedimensional market considerations to these broader challenges of a transition towards a low-carbon economy. In particular, I will argue that this widened perspective should include the need for new players who might challenge established patterns of actions in the energy field.

In this vein, I will argue that a political approach to making decisions on one ideational fundament alone - that of single market functioning and macro-economic concerns of short-term cost-efficiency - will not be appropriate to sufficiently address these challenges of a sustainable energy system transition. Consequently, this paper sheds light on transnationally interlinked subnational and societal activities, where a new paradigm is emerging for addressing these transition challenges. I will argue for strengthening the role of communities, municipalities and regions in the European multi-level-system of decisionmaking, as it was their specific framing of transition challenges as well as additional benefits in terms of local and regional development, job creation and reliance of indigenous energy sources, that to a great extent motivated and legitimized respective innovative activities and investment in renewable energy sources thus far across Europe, particularly in Germany.

\section{Europeanization of climate and energy policy}

\subsection{The degree of vertical integration in the current climate and energy policy framework 2009-2020. A brief overview}

European energy and climate policy has a long history; during this process the modes of policy coordination developed from very loose intergovernmental coordination of decentral member state policies to stricter forms of regulatory harmonization in selected policy fields (J ordan et al. 2010; Hildingsson et al. 2011; Wettestad et al. 2012, Geden und Fischer 2014). Alongside this development, a partial turn from an intergovernmental to a supranational mode of governance occurred, particularly regarding competition law within the European single market (e.g. McGowan and Wilks 1995). However, European policy integration is not characterized by a consistent and uniform degree of integration across policy fields. Instead, we can find substantial differences with regards to the degree to which Member States transfer authority to the European level. According to the literature ${ }^{1}$, there are at least three applicable criteria to determine the degree of vertical integration: the degree of legal bindingness of targets; the degree of regulatory harmonization of policies and measures; and the degree of EU-level institution-building (cf. Wettestad et al. 2012). These three criteria will be used to briefly characterize the current energy and climate policy framework of the European Union.

\footnotetext{
${ }^{1}$ For example Radaelli 2003, Börzel 2005; Schimmelpfennig and Rittberger 2006, Leuffen et al. 2013.
} 
The energy and climate policy framework for 2009-2020 consists of the following core elements: the three-pillar-based energy and climate target architecture, its related policies, and the completion of the Single Energy Market. The degree of harmonisation of national policies substantially differs with respect to these policy objectives.

In March 2007, the European Heads of State and Government agreed on the three-pillarapproach in defining energy and climate policy targets. By 2020 greenhouse gas emissions should be reduced by $20 \%$ the share of renewable energy in gross final consumption must increase to $20 \%$ and energy efficiency should be improved by $20 \%$ While the Member States have agreed on a legally binding character for the first two targets, the energy efficiency target is only indicative. With these targets, the European Union has a reputation as a pioneer in climate protection worldwide.

After tough negotiations between the Member States, a comprehensive energy and climate policy package for the period up to 2020 was adopted in 2009.

The European Emission Trading System (ETS) - the flagship of the European climate strategy to achieve the GHG-reduction target - became more functional with an agreement on a high degree of regulatory harmonisation of allocation methods. To the end of achieving the renewable energy target, the Renewable Energy Directive was adopted. The Directive provides that each Member State must achieve a certain percentage of energy from renewable sources by 2020. However, Member States have significant national discretion over the means and policies employed to meet these targets. Thus, due to the very diverse national interests and preferences, as well as diverse path-dependencies in the organization of national energy systems in terms of administrative structures and regulatory patterns, policy styles, Member States agreed on a low level of regulatory harmonization regarding support schemes for renewables.

With respect to the policies and measures put in place to achieve the efficiency target, the degree of regulatory harmonization varies. For instance, we find a rather high degree of regulatory harmonization for product-related measures (e.g. ECO-Design-directive, Directive on energy labeling) according to single market logics. There is a distinct regulatory picture of those efficiency policies, which are not directly linked to the free movement of goods and services. The European Energy Efficiency Directive, adopted in 2012, includes among other objectives - an indicative national target for Member States and a provision that each member state shall introduce an energy efficiency obligation scheme². However, Member States may opt out of introducing such a scheme and may alternatively choose

2 Energy efficiency obligations are mandatory energy targets for energy companies to be delivered through end-use energy efficiency measures. For an excellent overview and comparison of practical examples of energy obligation schemes in Europe, please see Steuwer 2013. 
other measures to fulfil the saving target ${ }^{3}$. Thus, Member States did not agree to fully harmonize policies for achieving energy efficiency targets.

The other core element of the 2009 energy and climate policy package is energy market integration. The integrated EU energy market, a core concern the European Commission has pursued since the late 1980s, should ensure the achievement of the aforementioned targets in a cost-efficient way through the free and cross-border transfer and trading of gas and electricity. Thus, related policies aim at the coupling of energy markets across Europe and at dismantling diverse restrictions and physical barriers to cross-border exchange and trading. During negotiations on the adoption of the third internal energy market package in 2009, the Member States did not, however, agree on any substantial transfer of national authority to the EU level. In particular, the Member States disagreed on a unified model of unbundling of energy utilities - as was preferred by the European Commission (EC) - due to different national and historically developed regulatory structures and traditions in organizing national energy systems. Some moderate Europeanization effects can be observed in terms of the integration of national transmission systems. New supranational institutions (ENTSO-E, ENSO-G, ACER) ${ }^{4}$ were established and equipped with moderate decision-making powers in order to reduce institutional barriers to cross-border grid-bound energy flows. These institutions replaced the previously voluntary coordination between national regulatory authorities and network operators (Wettestad et al. 2012).

\section{2 Europe at a crossroad? The shaping of the post-2020 energy and climate policy framework through the prism of single market integration}

In March 2013 the European Commission (EC) began a discourse on the new energy and climate policy package for the time after 2020 with its Green Paper "A 2030 framework for climate and energy policies" (European Commission 2013a) ${ }^{5}$. From the very beginning it was clear that the Commission envisioned significant changes in the framework. Relevant modifications relate to the target architecture, and also to a reinforced supranational pressure to harmonize national RES-support schemes. In the following, I will argue that these alterations are recommended by the EC not for effectiveness reasons, but because of core beliefs within EU supranational institutions regarding cost-efficiency and market com-

3 For a further discussion on the implementation of the European Energy Efficiency Directive see Steuwer 2014.

4 ENTSO-E/ G = European Network of Transmission System Operators for Electricity/ Gas. The ENTSOs propose and coordinate the definition of principles and procedures regarding the conditions for access to the network for cross border exchanges of electricity and gas. ACER = Agency for the Cooperation of Energy Regulators coordinates regional and cross-regional initiatives which favour market integration. It monitors the work of ENTSOs and their EU-wide network development plans and the functioning of gas and electricity markets in general, in particular wholesale energy trading.

5 The European Commission is the institutional actor, which has the right and the mandate to develop the proposal on the new framework to the Council and the parliament, which will ultimately decide and adopt the new framework in October 2014. 
patibility. This underlying framing of the problem implies certain policy choices regarding the adequate policy level to act on within the multi-level-EU-system and policy instruments (cf. Hildingsson et al. 2011).

\section{The break with the three-pillar approach in the target architecture}

The Commission's Green Paper situated the question of the types, nature and levels of targets and their interactions at the centre of the consultation process. Due to diverging views among Member States and stakeholders on the character of these interactions - ranging from mutual support to trade-off - the Commission suggests the necessity of checking "whether new targets for renewable energy and energy efficiency would be necessary to deliver further progress in the 2030 perspective" and "[...] whether having only a GHG emissions target for 2030 would be appropriate, taking into account other objectives such as security of supply and competitiveness." (European Commission 2013a: 7)

Parallel to the public consultation process, the commission's working staff has conducted a comprehensive impact assessment (IA) to assess the different policy options regarding target architecture and levels of targets in order to back the final decision of the EC with its findings (European Commission 2014a).

Figure 1: Main findings of the impact assessment of policy options regarding target architecture

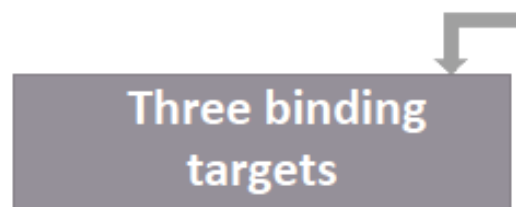

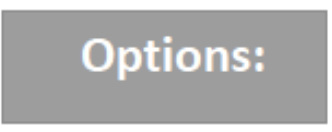

versus
One target only for GHG-reduction

Results of the Commission's working staff impact assessment:

\footnotetext{
- Risk of a reduced flexibility of member states to use other low-carbon energy sources (e.g. nuclear, CCS)

Higher additional benefits relating to

- Fuel efficiency

- Security of supply (greater reliance on indigenous energy sources)

- Environmental and health impacts

- GDP and employment
}

Higher increase of system costs in the short/medium term that pay off in the medium to long run (due to higher investments costs in efficiency and RES)

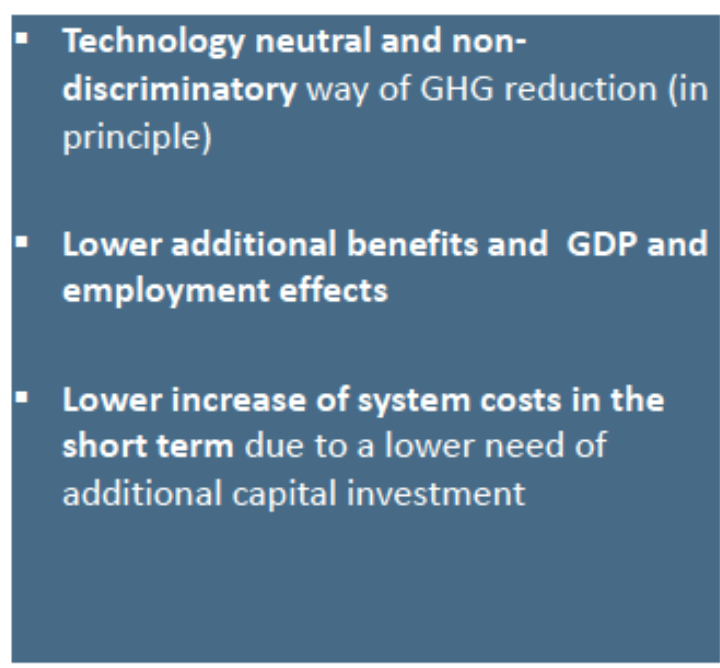


Regarding the question as to whether to have only one GHG-Target or to proceed with the three-pillar-approach, the commission's working staff's impact assessment found higher additional benefits in the case of a three-pillar-approach on the one hand, but equally perceived the risk for Member States to continue with other low-carbon energy sources and technologies incentivised by the ETS, like nuclear power or carbon capture and storage (CCS) on the other. "A single GHG target would in principle treat options for GHG reductions in a non-discriminatory and technology neutral way. However, higher efforts geared towards energy efficiency and renewable energy beyond what is needed to achieve a GHG target would result in higher benefits relating to e.g., improvements in fuel efficiency, security of supply, reduction of the negative trade balance for fossil fuels, environmental impacts and health. A single GHG target is also expected to result in lower GDP and employment compared to a framework based on more ambitious targets for also renewables and energy efficiency, while macro-economic benefits associated with the recycling of auctioning revenues into lower labour costs would increase" (ibid: 15). Furthermore, it was calculated that in the short or medium term the overall system cost increase would be higher in the case of a triple target architecture, due to higher up-front investments in efficiency and renewable energy sources. These costs, however, will pay off - but only in the medium or long run (ibid: 16; see Figure 1). Thus, the impact assessment did not result in clear recommendations. Instead of arguing for a single-target solution, it emphasized various benefits of a three-pillar-approach. Nevertheless, the final decision of the EC, which was formalized in its communication to the council and the parliament, is based on a very selective perception of the balanced and sophisticated work done by its own staff and only emphasizes the short-term cost increase of the three-pillar approach. The Commission In J anuary 2014 finally concluded that one binding GHG target only "[... ] represents the least cost pathway to a low carbon economy which of itself should drive an increased share of renewable energy and energy savings in the Union." (European Commission 2014b: 5) ${ }^{6}$.

The Commission additionally justified the one-binding-target-only approach with the higher flexibility of Member States to achieve $\mathrm{CO}_{2}$-reductions with the non-discriminatory and technology-neutral nature of such a single target. Regarding the additional benefits of the three-pillar-approach, which were emphasised in the Commission's staff impact assessment and in many of the stakeholder statements in the public consultation process of the Green Paper, the EC qualifies their importance with the following arguments: "Experience with the current 2020 framework indicates that while European and national targets can drive strong action by the Member States and growth in emerging industries they have not

6 For RES the EC proposes a headline indicative target of a $27 \%$ share in final energy consumption by 2030 , a target which is of non-binding nature for Member States. A precise number for the recommended ambition regarding energy efficiency was only delivered in J uly 2014 and completes the EC proposal of the future climate and energy policy framework up to 2030: the EC suggests in its Energy Efficiency Communication a headline indicative target of increasing energy efficiency by 30\% by 2030 (European Commission 2014c). 
always ensured market integration, cost-efficiency and undistorted competition." (European Commission 2014b: 5, author's emphasis).

The increased flexibility of Member States, however, to deliver GHG-reduction, at first sight seem to be contradictory to the Commission's intensified efforts to finally come forward with a regulatory harmonization of support schemes for renewable energies, which, in fact, restricts national flexibility.

\section{Flexibility of Member States versus a strong European governance framework: An in- herent governance dilemma within the EU}

From the European Commission's perspective, there is no antagonism between its notion of flexibility regarding the choice of low-carbon energy sources to achieve the GHG objectives and the need for a "strong European governance framework accompanying the single target" (ibid: 6) - precisely, the reduction of national flexibility regarding instrument choices for RES support schemes. Instead, the Commission argues that the strong European governance framework accompanying the single target should aim at delivering "[...] EU objectives for renewable energy and energy savings in a manner that is consistent with attainment of national and European greenhouse gas targets and coherent with the wider principles of European energy policy: the operation and further integration of the internal energy market and the delivery of a competitive, secure and sustainable energy system" (ibid: 6, author's emphasis).

This statement reveals the main rationale and the problem framing of the need for energy policy co-ordination by the EC: it is an internal market concern, instead of a concern about the promotion of innovative approaches to prevent climate change. However, looking at the need for energy policy coordination solely through the prism of market integration (cf. Hildingsson et al. 2011) places any national policy provision to support nationally desired developments under suspicion that it will create serious market distortions. This perspective on the need for strong European governance comes into conflict with another governance mechanism in multi-level-systems, which is described in the literature: regulatory competition to bring about innovative policy solutions. The term regulatory competition relates to the dynamic in multi-level system to bring about and politically compete with policy innovations. The de-central level is assumed to be an appropriate level in which to develop and experiment with policy innovations ("laboratories of innovation"), which may later - whether as a result of competitive dynamics between the jurisdictions or as a result of policy learning - diffuse horizontally or vertically (e.g. Oates 1998, Heritier et al. 1996, Kern 2000, Holzinger and Knill 2004, Tews 2005).

Thus, if the Community wants to promote regulatory competition and a substantial "race to the top", it must allow for substantially greater regulatory diversity. However, regulatory diversity, in turn, will automatically lead to distortions in the free movement of goods and thus infringe one of the founding principles of the Union (cf. Dalhammar 2007). 
This is an inherent governance dilemma that the EU has faced from of its initial pronouncement of market integration as the driving principle of European integration. It has also been an issue of longstanding political and scientific debates on the interrelation between single market and environmental policy (e.g. Scharpf 1996, Weale et al. 2000, Macrory 2006, J ordan et al. 2010). Legal and political scientists have revealed both synergies within this interrelation, but equally inevitable tensions between the functioning of the single market and the implementation of environmental policy ${ }^{7}$. Compatibility suffers from the multitude of contradictory rules and principles regarding both targets in EU treaty provisions, which are not ranked. There is more a "living together" of contradictory targets, rules and principles (Torre-Schaub 2006). Consequently, divergences arise especially around the question of how much discretion should be left to the Member States to develop national policy approaches, which might come into conflict with single market rules. Clarification about a prioritization can often only by delivered by case law decisions of the European Court of J ustice (ECJ ) ${ }^{8}$.

Different types of policy coordination regarding market integration and environmental policy have been described as consequences of different interest constellations among Member States (e.g. Scharpf 1996). Market integration within the EU is a politically driven process of eliminating trade and investment barriers, as well as competition distortions, between the members of the EU. It is a process of integration through the replacement of differing national legal provisions concerning these issues with harmonized European legal provisions. Environmental protection within the EU - although equally a field of European action with a legal mandate since the adoption of the European Single Act in 1986 - can rely significantly less on this type of full regulatory harmonization. Only with regard to environmental standards, which directly affect single market requirements, is a similar type of full harmonization observable (product norms). Thus, regarding environmental standards, national legal provisions are not usually fully replaced by European rules. The desired levels of standards and the choices of instruments are nationally defined according to heterogeneous national preferences, path dependencies and regulatory patterns (e.g. Knill 1998, Börzel 1999).

Thus, a full harmonization comparable with single market provisions is hard to achieve. It is furthermore not desirable, as it would hinder regulatory competition between jurisdic-

7 For a legal literature review concerning the tensions between single market and environmental provisions in the EU see Tews and Vagt 2010.

8 Although the Court has added substantially to the Treaty provisions and has strengthened the role environmental considerations the case-by-case nature of the Court's solutions has also demonstrated the limits of such an approach. Scientists have pointed at the risk of a "regulatory chill", precisely the danger of a lack of regulatory action in the Member states. Afraid from eventually being overruled, Member States might refrain from taking ambitious action and instead wait for the supra-national actor to take decisions. While it appears from a number of different cases that the Court is ready to accept national derogations on grounds of stricter environmental standards, Member States seem to be rather cautious in actively "challenging" the Commission (Tews and Vagt 2010: 60). 
tions, which spurs adaptive policy innovations and subsequent horizontal learning processes.

Primary as well as secondary EU law left significant discretion to Member States on environmental and, since the Lisbon Treaty, energy matters. Under these conditions, however, national provisions often come into conflict with basic single market rules. Therefore, the likely conflict of interests between environmental protection and the European single market has been manifested in the legal provisions of the European Union since environmental concerns were first the subject of community law in 1986 (Torre-Schaub 2006: 12 pp.; Pagh 2006:3). Moreover, this tension has not been fully resolved by any of the amendments of the EU's Treaty provisions. Instead, with the adoption of the Lisbon Treaty in 2007, energy policy - as a traditionally national competence - was defined as a subject of community activities. Consequently, the previously described tension was extended to energy issues ${ }^{9}$.

\section{Supranational pressure to force regulatory harmonization in RES support schemes}

The long lasting struggle in the EU over RES support schemes is a very suitable example of this inherent governance dilemma. The European Commission has repeatedly made attempts to harmonize national support schemes on renewable energies and to promote a specific instrument as the most market compatible (cf. Busch 2005, Lauber 2011, Jacobs 2012). The rationale for regulatory harmonization is based on the neo-liberal perception that regulatory diversity conflicts with basic provisions of single market integration and leads to market distortions. Quota systems with tradable certificates were the first preferred instrument choice of the EC, as quota systems were perceived as the adequate instrument choice in an integrated energy market. As early as 1998, the EC saw no alternative to an instrumental shift and regulatory harmonization: "the move from a fixed tariff approach towards one based on trade and competition is at some stage inevitable" (European Commission 1998: 17; quoted in Busch 2005: 241). However, this volume-based economic instrument was not preferred among the majority of European countries. Instead, price-based feed-in-tariff-systems diffused among Member States (Bechberger et al. 2003, Tews et al. 2003, Busch 2005), especially due to their effectiveness. Current surveys indicate that there is a growing trend towards European convergence of national support schemes based on price-based economic instruments, such as guaranteed feed-in tariffs followed by guaranteed market premiums - which some scholars characterize as subcategories of feed-in-tariffs (Kitzing et al. 2012; J acobs 2012, ecofys 2014.).

The most ostensibly market compatible quantity-based quota-system did not perform well in practice, as a recent study on design matters of RES-support schemes in an integrated energy market reveals. "Empirical evidence concerning quota system shows that the theo-

9 For a related critical discussion on the normative desirability for and the legal and political feasibility of an Europeanization of energy policies of Member States see Strunz et al. 2014a. 
retical advantages of quota systems could not be realized in practice. The recent substitution of quota obligations with other support mechanisms in three large countries - UK, Italy, and Poland - suggests a trend moving away from using quota obligations in Europe" (ecofys 2014: 81).

So far, Member States have been able to fend off the supranational pressure for harmonized RES-support-schemes. They may do so by referring to constitutional provisions of the EU primary law which defines the "[...] Member State's right to determine the conditions for exploiting its energy resources, its choice between different energy sources and the general structure of its energy supply [...] (Art. 194 TFEU) as well as by referring to EU secondary legislation, specifically the RES-Directive (2009/28/28/28/EG), which provides national discretion over the means and policies for achieving mandatory national RES-targets.

Figure 2: The inherent governance dilemma in European RES-policy and the new attempt to define adequate policy levels and instrument choices



Source: Own illustration

As is the nature of a dilemma, the problem is inherent and thus persistent: It is an equally constitutional provision of EU primary law that enables the EC to renew its attempts to harmonize national RES-support schemes using the lever of the competition law (see Figure 2). Concerning single market integration, Member States have transferred national authority to the supranational level to control and sanction compliance with single market rules. 
Thus, the EC has the discretionary power to decide whether to commence an infringement procedure against competition rules and to refer a case to the European Court of J ustice.

It is becoming apparent that the European Commission's efforts to bring about regulatory harmonization have intensified since the end of 2013. These efforts include the revision of the state aid guidelines, as well as the opening of infringement procedures against national support schemes - in particular, against the German scheme. In December 2013, the Commission submitted a new draft of its guidelines on environmental and energy state aid. The Commission's state aid guidelines, simply speaking, define exemptions to the general prohibition of state aid in the internal market and define specific justifications for state aid which supersede competition rules. Since the introduction of the European Single Act in 1986 they have been an effective means for the EC to extend its own scope for action against Member States. As a kind of European "soft law" - these guidelines are not directly binding for the Member States. However, due to their binding effects for the Commission's decisions on the state-aid rules conformity of national provisions, they have a meaningful law-shaping effect on the national policies of Member States (see Hartlapp and Bauer 2011). These new guidelines on state environmental and energy aid contain provisions which seriously interfere with Member States' national authority to shape support schemes for RES.

The draft of the new guidelines on environmental and energy state aid published in December 2013 entailed a provision concerning the design of national support schemes for RES, which will be considered compatible with the Commission's perception of a proportionate state aid which does not distort competition to an extent contrary to the internal market.

The draft defined feed-in-tariffs as a non-market compatible instrument. State aid for electricity from renewable energy sources will only be considered compatible with the internal market if the aid is granted as a premium in addition to the market price; the level of granted aid has to be determined by a technology-neutral, competitive bidding process. Furthermore, the Commission drafted an additional requirement that Member States have to open their national support schemes for renewable electricity generated in other countries $^{10}$.

10 Concerning the latter, the then pending ECJ-case of the Finnish Ålands Vindkraft AB against the Swedish support scheme for renewable energies is relevant. According to the opinion of the advocate general Yves Bot, the case "presents the Court with a fresh opportunity to rule on the consistency with EU law of national support schemes for energies produced from renewable sources under which the support is reserved to electricity producers located on the national territory" (Case C-573/ 12, opinion). The Finnish producer Allands Vindkraft appealed to the Swedish courts on the grounds that the Swedish support scheme violated core "free movement of goods" principles and, specifically, the provisions of Article 34 of the Treaty on the Functioning of the European Union to the extent that only producers of renewable energy located in Sweden could benefit and imported renewables were otherwise excluded or discriminated against. In December 2012, the Swedish higher courts referred the matter to the ECJ. In J anuary 2014 the final opinion of the advocate general was published, which was in line with the drafted European Commission's state aid requirement to open national schemes to producers from outside. According to Bot's conclusions, a scheme re- 
After a process of public consultation, the new guidelines were adopted in April 2014. Due to the substantial number of critical comments and negotiations with Member States, who insisted on more flexibility in the financing schemes, some slight corrections have been made. First, the adopted guidelines now consider the different stages of technological development of renewable energy technologies and allow technology-specific auctions. Second, the required opening of national support schemes to foreign producers was slightly softened, due to the pending cases in front of the Court of J ustice concerning the issue (see footnote 10): "Operating aid schemes should in principle be open to other EEA countries and Contracting Parties of the Energy Community to limit the overall distortive effects" (European Commission 2014d; author's emphasis). Third, although the Commission maintains its preference for market premiums to be determined through competitive bidding processes, the guidelines now contain a provision for a so-called opt-out-option from the tender mechanism, if:

- "Member States demonstrate that only one or a very limited number of projects or sites could be eligible; or

- Member States demonstrate that a competitive bidding process would lead to higher support levels (for example to avoid strategic bidding); or

- Member States demonstrate that a competitive bidding process would result in low project realisation rates (avoid underbidding)" (ibid. ).

If Member States can provide evidence for these opt-out criteria, then aid must be granted as a market premium instead of fixed feed-in tariffs. However, this cannot occur in the case of negative market prices. The mandatory direct marketing and market premiums have to be introduced by 2015 for generation facilities over $500 \mathrm{~kW}$ ( $3 \mathrm{MW}$ wind). If Member States do not provide the evidence for opting-out, than by 2017 any other support scheme for RES-electricity will be presumed to be unjustified state aid and the Member State will risk the opening of an infringement proceeding by the European Commission.

Legal analysts confirm the political assessment that, with the provision of such detailed specifications in their guidelines, the Commission is using the competition law to shape energy policy and is thus seriously intervening in the constitutionally defined rights of Member States. "The EU state aid law is not a priority 'meta-law' that per se overrules other EU jurisdictions. Consequently, EU state aid law does not automatically break EU en-

stricting access to its support for electricity generated at the national territory is not compatible with basic provisions of single market regulation and therefore invalid. However, The ECJ on 1st July delivered against any expectation - a landmark decision which deems the Swedish green certificates scheme in conformity with EU law. It confirms that, based on the Renewable Energy Directive 2009/28/ EC and the Treaties, national governments can continue restricting access to their support schemes for renewable electricity generated on their territory. 
ergy law. [...] Some of the criteria of the state aid guidelines violate the provisions regarding the energy policy competence level as defined under Article 194 TFEU and the Renewable Energy Directive 2009/28/ EC" (CEP 2014: 2; author's translation into English).

In parallel with the publication of the draft guidelines, the Commission opened a state aid infringement procedure against Germany in December of 2013. In order to understand the relevance of this infringement procedure within the struggle over support schemes, it is important to note that the German FIT-scheme has been recognized by many scholars and practitioners as a role model for subsequent national adoptions of similar FIT/FIP-based support schemes in a several other European countries.

Although the state-aid conformity of the exemptions granted for German electricityintensive companies regarding the renewable energy surcharge has ostensibly been the subject of the procedure, there is some evidence that suggests the opening has been motivated instead by a desire to establish an additional lever to further substantiate the Commission's demand for harmonized support schemes in its preferred direction.

The Federal Energy Minister Gabriel assessed the opening of the proceedings as a "detour via competition law to have access to an area where the Commission actually has no jurisdiction" (quoted in photon 09/01/2014; author's translation into English). German economists and lawyers, including the President of the Federal Network Agency, had earlier signalled that the pending infringement proceedings will unlikely have a dramatic impact on the German economy, as the adaptation requirements would be more about marginal deletions of privileges (quoted in FAZ, 11.01.2014, p.14). Consequently, the results of the negotiations between Minister Gabriel and Competition Commissioner Almunia have shown that the dispute over exemptions was more about the compatibility of the respective legal provisions to grant exemption than about the sheer size of "subsidies" / exemption grant$\mathrm{ed}^{11}$.

What becomes important in this proceeding is a side effect: a pending infringement proceeding can create immense pressure for national action. In particular, the Commission's decision to initiate an infringement procedure results in the so-called Standstill requirement (Article 88, TFEU), which is precisely the immediate suspension of the controversial national provision. In the case of the opening of the infringement procedure against Germany, the EC's decision suspended further grants of multi-billion EUR exemptions to German energy intensive companies until a final clarification of the case or a timely amendment of the national legal provision (The Renewable Energy Act), with prior notification and approval by the European Commission, is made. It seems obvious that the Commission

11 An analysis of the FÖS (Green Budget Reform Germany) shows that almost $90 \%$ of industrial sectors will be granted for exemptions according to the revised Renewable Energy Act, which base on the negotiations with Almunia. Thus, the federal government exhausted the maximum scope permitted by the European Commission (FÖS 2014). 
did not really intend to curtail advantages for German industry, as the main engine of the European economic development, in such an extreme manner. Instead it is (mis) using its discretionary power in competition matters as a compulsive lever to enforce regulatory harmonization of national support schemes for renewable energy, according to its perceptions of market compatibility and cost-efficiency.

\section{Implications for the German energy transition process and govern- ance options for a low carbon energy system transition}

In this section I will analyse the implications of the discussed changes in the European energy and climate policy framework for the German energy transition process. Furthermore, the section will combine this analysis with a discussion of the respective governance options for dealing with these consequences - both against the background of the special German path to energy system transition as well as against the general background of the challenges of a transition process towards a low carbon energy system.

The German approach to energy transition is based on four main pillars: nuclear phase out, an expansion of renewable energy sources, an increase in energy efficiency and the reduction of GHG-emissions. Rapid success in the use of renewable sources has been mainly driven by a (previous) policy framework, which has attracted investments from a variety of actors, especially private consumers, communities and energy cooperatives (e.g. trend:research and Leuphana Universität 2013). Meanwhile, the market diffusion of renewable energy technologies for generating electricity has reached a new stage, where the need for policy-coordination between distinct levels of jurisdiction has become obvious (Ohlhorst et al. 2013). However, for a long time there has been a tendency to limit discussions, particularly on contested distributional issues, to domestic matters, such as a German electricity market design, and the need for greater political coordination between the jurisdictions within the German federal system. Only recently has the political relevance of European policies for the German energy transition been given much higher political attention - enforced, of course, by the conspicuous signals given by actors at the European level.

For some time there have been diverse voices in the German debate which have pointed to the shortcomings of a purely national perspective on the coordination requirements. However, they argue from very different perspectives. Despite some commonalities regarding the rising tensions between Germany and Europe and the induced adaptation pressure on the German policy of energy transition, the policy suggestions regarding the required adaption strategies substantially differ. One discourse coalition argues that Germany's decision to follow its own path in energy system transformation threatens the EU's efforts to achieve a cost-efficient transformation of energy supplies within the European energy market. Following this logic, Germany must modify its plans and respective instruments to 
fit with the expectations of the European energy market (e.g. Böckers et al. 2013, Hübner et al. 2012, Haucap and Kühling 2013) ${ }^{12}$.

Another coalition expresses concerns that EU-level politics pressuring Germany to modify its ambitious approach to transforming its energy system. This position is grounded in the perception of the German path for energy transition as a potential role model, which, given that it provides evidence for feasibility, might motivate other countries to follow. As a consequence, they call for an "Europeanization of the German energy-transition-politics" (Fischer and Geden 2011, Geden and Fischer 2014) or even to "globalise the German energy transition" (Westphal 2012). In this vein, scholars argue that Germany should initiate European energy transition politics that would accompany the German energy transition.

The following paragraphs will show, however, that the German government has so far failed to transfer basic ideas from the German de-carbonisation pathway to the European level and to initiate favourable European-level framework conditions.

\subsection{An unfavourable target architecture}

According to many stakeholders and scholars, a GHG target alone, with the EU-ETS as the lead-instrument of climate protection, will never set enough incentives to invest in diverse renewable energy sources and in energy efficiency, as per the suggestions in the Commission's final proposal to the council. ${ }^{13}$ Instead, it will lead to a strengthening of those energy actors which operate according to the logics and structures of the traditional configuration of electricity production (based on large centralized nuclear and fossil fuel power-plants), while the latter gain ground in climate change issues by the promotion of CCS.

The implied neutrality regarding the choice of low-carbon technologies in the proposed single target architecture clearly conflicts with the German approach to the energy transition. According to the recommendations of the Ethics Commission and important policy course decisions by the German Bundestag, the pathway to a low-carbon energy system should be based on the aforementioned trademarks: nuclear phase-out, an increase of RES in the energy mix and increased energy efficiency (cf. Schreurs 2013). Additionally, the use

12 For a critical discussion of these positions please see Strunz et al. 2014b.

13 Concerning the shortcomings of a single price signal given by the EU-ETS to address the existing barriers for the development of the energy technology mix, which is needed for energy system transformation, see Matthes 2010; Hey 2012, Lehmann und Gawel 2013. For a sophisticated discussion of the need for policy mixes from an economic theory perspective, please see Rave et al. 2013: 120 pp.

Furthermore, one can consider the Commission's staff's impact assessment (EC 2014a), which modelled the different target options. It reveals that the results of the single target scenario, which backed the Commissions final decision to propose the single target approach, are based on the assumption of a carbon price of $€ 40$ per tonne! Compared to the current price of around $€ 5$ a tonne and the strong opposition of business lobbies to any attempts to raise this price, it is quite plausible to question this figure: "Where is the political majority for that sort of carbon price?" (Green MEP Claude Turmes, quoted in EurActive, J une 232014 : http:// www. euractiv. com/ sections/ energy-efficiency-buildings/ eu-paper-pencils-30-or-35-efficiencytarget-2030-302972). 
of other low-carbon technology options to meet climate change objectives, in particular carbon-capture and storage (CCS) is not intended, according to the (still valid) conclusions of the respective German policy discourses. Thus, the avenue Germany wants to take to transform its energy system is not characterized by treating options for GHG reductions in a non-discriminatory and technology-neutral way. Instead, it discriminates between wanted and unwanted low-carbon-technologies - due to the respective public attitudes towards energy technologies and the policy-makers' responsiveness to those attitudes. Germany further discriminates with regard to the maturity of wanted technologies - by technology specific feed-in-tariffs or premiums.

The Germans' ambitious approach is a sharp contrast to the majority of national energy strategies of other Member States, which follow their own preferences according to their energy mixes, their historically developed domestic energy system structures and their path dependencies. However, in an integrated energy market, one cannot politically restrict the cross-border trade and exchange of electricity produced by unwanted technologies; electricity is traded in the market as a homogeneous good and its competitiveness is almost fully determined by its price in the market.

\section{A possible complementarity of governance options: leadership in multi-lateral negotia- tions, bilateral cooperation and horizontal processes of policy diffusion}

Thus, to maintain the credibility of its own climate protection ambitions, to maintain domestic public support for an energy transition based on renewables and, most probably, to maintain competitiveness, the German government must prevent any development which improves the European framework conditions for the use of nuclear energy and pronounce the prominent role of renewables in transforming the European electricity/ energy system (Geden and Fischer 2014). The latter is not only relevant to ensure minimum incentives, given that other Member States will try to expand their renewable shares, but also against the background of the previously described struggle over state aid compatibility of national support schemes for RES. As Geden and Fischer argue "Even a weak target for RES at the European level would imply a prioritized role of renewables compared to that of conventional fuels. This would help in controversies between the Commission and Member States over the single market compatibility of national support schemes" (ibid: 20; author's translation). Precisely, it would influence respective case-law-decisions of the ECJ in the future (see the discussion above).

In sum, the following strategic options to bolster the German energy transition can be identified and will be described in the next paragraphs:

- Leadership at intergovernmental level

- Co-ordination at bilateral level

- Assisting transnational activities at subnational level.

Taking a leadership position in the European negotiation on future energy and climate policy framework would require a more pro-active role of the German government at the Eu- 
ropean level to influence final outcomes for the framework, which will be adopted at the Council meeting in October 2014. The assumption of this leadership role was urged in an open letter from European NGOs outside of Germany to Chancellor Merkel in February 2014: "It is time for Germany to start leading again! We urge you to step up and make Germany the EU leader we need on climate and energy policy" (open letter of European NGOs outside Germany to Chancellor Merkel, February 2014). Germany's leadership would imply a consequent positioning in favour of the triple target architecture. The German government then would be required to advocate, first, for an ambitious target for GHGemissions combined with an enhanced European ETS, whose current crisis seriously counteracts the increasing share of renewables in the German electricity consumption, and second, for a binding renewable energy target, particularly for the electricity sector. In that sense, the German government started several initiatives in 2014 with counterparts of other Member States, in which they defined their joint position in favour of a triple target architecture. However, regarding the RES-target, the message is not as clear as it initially seems, as the government calls for an ambitious European "binding" target, but the degree of bindingness for Member States remains somewhat blurred ${ }^{14}$.

Given the restricted political opportunities to reach a consensus during the multilateral negotiations to proceed with the previous European approach in energy and climate policy, it would be favorable to create front-runner alliances among governments of willing Member States, e.g. Denmark, Austria or even France ${ }^{15}$ and to enhance efforts for bilateral cooperation even with countries, which so far perform as blocking force at the intergovernmental European level - as for example the Visegrád Group.

Such bilateral cooperation might also utilize the potential of a third governance option to come forward with a sustainable energy system transition, one which is often overlooked in the debate on the diverging positions of Member States: A possible and potentially complementary pathway for Europeanization beyond vertical integration through negotiated agreements at an intergovernmental level is a horizontal process of diffusion of problem

14 For example, in a joint declaration of the German-French Council of Ministers in February 2014 on Energy, climate and sustainable development, both governments called for a binding target for RES at $30 \%$ However, the declaration also provides that Member States should have the flexibility to set domestic targets, according to their opportunities. http:// www. bmwi. de/ BMWi/ Redaktion/ PDF/ E/ gemeinsame-erklaerung-deufra-energie-klima, property $=\mathrm{pdf}$, bereich $=$ omwi2012, sprache $=$ de, $r w b=$ true. $\mathrm{pdf}$ ). Thus, it is questionable whether the German government wants to actively promote the approach used in the current RES-Directive, which obliges Member States to achieve a certain percentage of energy from renewable sources by 2020 and only makes flexible the means to achieve these targets.

15 Concerning France's motivation to engage in ambitious EU climate protection targets and measures, even in the field of RES and energy efficiency please see, Fischer and Geden 2014. They argue that France, as the host of the next UNFCCC-meeting in Paris in November 2015 (which will to attempt to establish consensus on a post-2020 global climate change framework) has an interest in a success of the COP 21. Success will be only possible when the EU will convincingly demonstrate that it has not lost ambition within its own energy and climate policy (ibid.: 18). 
framings, attitudes, ideas, and even policies through transnational actor networks (Tews and J änicke 2005, Tews 2006, Hakelberg 2014, see also footnote 17).

When considering only government positions it is easy to overlook what happens at subnational level, especially in countries that are often portrayed as being reluctant to accept ambitious climate objectives. Surveys indicate that across Europe the public attitudes toward preferred energy technologies clearly correspond with the German path for energy transition (e.g. EC 2013). A majority of European citizens prefer RES and energy efficient technologies over nuclear power, fossil fuels, CCS and shale gas. In all 27 countries, RES is the most highly mentioned priority for energy options in the next 30 years. Respondents living in EU15 countries are more likely to mention RES than those living in the 12 new Member States (74\% vs. 57\%) (ibid: 100 pp) ${ }^{16}$. However, this attitude in Eastern European countries seems to have changed recently - particularly in reaction to the Ukraine crisis and the increasingly relevant issue of energy dependency on Russian gas imports. A recent public opinion poll on behalf of Greenpeace International in Poland, Czech Republic, Hungary and Slovakia (Visegrád countries) revealed that now $86 \%$ of the respondents in these four countries support EU-binding targets for RES. RES-development and increased energy efficiency are perceived by three quarters of respondents as a way of remedying import dependency (EURActiv 18.06. 2014).

At the subnational level we find many initiatives, not only individual grassroots projects, but also initiatives driven by local and regional authorities, which aim to accelerate energy transition. In Poland, for example, municipalities and local level administration show much greater support for a transition based on renewable energy sources then the Polish government does, as they perceive RES-deployment as a chance to combine climate protection efforts with additional benefits for their community's development (Ancygier and Sulecki 2013, 2014). Twenty eight Polish cities have already adopted ambitious sustainable energy action plans, based on the initiatives of the Covenant of the Mayors; more than 800 municipalities wish to develop low-carbon energy plans (Michniowksi 2014). Thus, there is great political potential for co-operation with regards to renewable energy projects at the subnational/local level.

There are several other transnational networks beyond the well-known "Covenant of the Mayors" engaging in lesson-transfer and -drawing activities for approaching a decentralized energy transition (Bulkeley and Kern 2009, Hakelberg 2914 ${ }^{17}$ ). The European association of

16 Renewable energy sources are most mentioned by respondents in Portugal (82\%), Austria, Spain, German and Denmark (all 81\%). In fact in only two countries are they mentioned by fewer than half of all respondents - Bulgaria (45\%) and Romania (49\%).

17 Lukas Hakelberg published the findings of an event history analysis, which show that the massive spread of local climate strategies is promoted by transnational municipal networks, which successfully deploy strategies for governance by diffusion. He points to the fact that their impact on that spread is exceeding that of most alternative explanatory factors cited in the literature. He concludes that such transnational networks can be expected to play a decisive role in a climate governance system that is becoming increasingly fragmented, polycentric, and transnational (Hakelberg 2014). 
local authorities in energy transition, "Energy Cities", was founded in 1990 and represents more than 1,000 towns and cities in 30 countries. All of these initiatives across the European Union are currently creating a new energy paradigm towards a low-carbon society, driven by the motivation to exploit untapped potentials for the deployment of renewable energy and energy efficiency at the local level.

Although the European Commission and national governments have brought attention to the local level's potential to develop innovative approaches in climate and energy, the motives of the actors at the de-central level to engage in the low-carbon-transition are completely neglected within the macro-economic and short-term cost-efficiency perspective, which underlies the Commission's choice of the single target approach. In fact, it is the additional benefits for the communities' development -in terms of jobs, security of supply, health and environment impacts, citizen's engagement in community issues and their wish to control energy supplies - which makes them active. However, for the European Commission these additional benefits, which were also pronounced in the Commission's staff impact assessment, seemingly fall under suspicion for being driven by measures which, "[...] have not always ensured market integration, cost-efficiency and undistorted competition“(European Commission 2014b: 5, see above).

A pure perspective on cost-efficiency, repeatedly put forward by Europe's Energy Commissioner Günther Oettinger, implies that market forces in the integrated electricity market would guarantee the most cost-efficient allocation of RES facilities across Europe. Precisely these market forces will spur a spatial allocation of facilities according to best available returns due to weather and geographical conditions. This perspective neglects that not the greatest return motivates bottom-up initiatives of communities and energy cooperatives. They do not want to invest somewhere in Europe. Instead, the additional benefits for their community's development motivate their investment in RES-facilities and efficiency measures in their "backyard". Moreover, relying solely on market forces to determine an efficient spatial allocation of facilities implies a perception of these bottom-up activities as strange within the energy system - as a kind of "infiltration" ${ }^{18}$ in the strategic action field of the established actors, the big energy utilities ${ }^{19}$.

However, the dispute over additional benefits reveals the subnational level activities and actors as relevant potential partners for Germany in shaping the European energy and climate policy framework. The German government, as well as the German Bundeslaender, argue with the additional benefits as well. They focus on the value added by the development and deployment of RES as well as by increased efficiency measures and the national

18 A term which apparently has been used by the Europe's energy commissioner Oettinger in a meeting with fellow Christian Democrats with regard to „citizens [that] have 'infiltrated' the German power sector with their grassroot Energiewende" (quoted in Morris 2014).

19 For a recent overview of strategies of the incumbent actors in the strategic action field of energy policy in Germany, please see the published first results of a study by Kungl 2014. 
security of supply by the greater reliance on indigenous energy source. Thus, a Europeanwide perspective on such a cost-efficient allocation of RES-facilities - as in the Commission's new strategic approach to market compatible climate and energy policy measures cannot also be in the interest of an array of German actors at different policy and administrative levels, as they do not offer the most competitive weather and geographical conditions among the European regions.

Thus, from the German perspective, it would be appropriate to strategically utilize this bottom-up and horizontal mode of convergence complementarily to multilateral negotiations at supranational level and to assist transnational actor networks of municipalities and regions in order to stimulate a horizontal diffusion of attitudes, ideas and good practices for a low carbon energy system transformation.

\subsection{A hasty government's adaptation to supranational pressure: the remaining gov- ernance options regarding instrument choice for RES support}

As described above, the EC's new state-aid guidelines specify design features of a national support scheme for renewables so that they meet the compatibility requirements of these guidelines. As a reminder, this will only be the case if the aid is granted as a premium in addition to the market price, while the level of granted aid must be determined by a competitive bidding process. Such volume-based auction or tender systems fundamentally differ from the scheme that Germany had applied over the years. Germany's scheme was a price-based support scheme, with administratively fixed prices for RES according to their technological maturity.

Theoretically, there would have been two alternative modes for the German government's response to this supranational pressure for such a fundamental instrumental shift: to provoke friction with the EC and to commence a proceeding to the ECJ on the one hand, or to adapt to the external pressure on the other. The government decided to pursue the latter.

It would, however, be a mistake to attribute this instrumental shift only to supranational pressure. Indeed, there has been a long-lasting domestic debate on the need to introduce cost- and volume controlling elements into the German scheme. Nevertheless, the pending infringement procedure and the subsequent standstill requirement (see above) led to a very hasty reform agenda and a rejectionist stance by the government on any stakeholder discussion over alternatives which might be in conflict with the Commission's state aid rules. ${ }^{20}$

${ }^{20}$ In a letter from mid-May 2014 Minister Gabriel urged the parliamentary groups to hurry in formulating any proposal for amendment to the Government's draft reform of the Renewable Energy Act (EEG) to the first week of J une. This would be necessary in order to ensure a timely examination of the legal text by the European Commission by the end of J une. The government's schedule would foresee an adoption of the new EEG law in the Bundestag on J une 26; on August 1 the new act should come into force. He argued that this schedule determined whether the law would be ready on time to grant the EEG surcharge exemptions for industrial companies due to the pending EU state aid proceedings. Otherwise, he clearly states, "the elec- 
The reform of the Renewable Energy Act was adopted by the parliament on J une 27, 2014. Concerning the design of the future support scheme, the reform fully adapts to the norms defined by EC's state aid guidelines; direct marketing will be mandatory by 2016. By 2017, the level of the market premium will be determined by a competitive price building mechanism via auctions. However, thus far no detailed design features of the auction mechanism are specified in the law.

\section{A careful instrument design by including normative elements}

Comparative studies clearly suggest that the potentials and risks of auctioning - which is supported by little empirical evidence in Europe thus far - depend on the specific design of the instrument (ecofys 2014, IZES 2014). It is not the aim of this study to discuss this design in detail. However, during the consultation process of the draft of the Renewable Energy Act, many stakeholders raised concerns against this mechanism, which is perceived to fundamentally change the framework conditions for those new actors in the energy field, who had driven the rapid expansion of RES in Germany.

At this juncture, it is necessary to briefly shed light on the most striking phenomenon of the German energy transition process. It is characterized by the rise of new energy actors, precisely de-centrally organized citizen's energy co-operations investing with or without local authorities' involvement in RES-facilities in their region. According to a recent market analysis in 2012, citizen engagement counts for $47 \%$ of total installed capacity in RES, in particular photovoltaic and onshore-wind capacity (trend:research and Leuphana Universität Lüneburg 2013: 42 pp). Thus, according to this ownership-type-based analysis, citizens and cooperatives have the largest share, while the energy utilities' share accounts for only $12 \%$ of the new installed RES-capacity (ibid.). The previous FIT-scheme and the guaranteed feed-in-priority for renewable electricity into the grid functioned as a shelter for renewable electricity producers to grow up in a protected niche. However, the returns in this niche-segment of the electricity market were apparently not high enough for the traditional energy utilities to invest (see Morris 2014, Kungl 2014). New actors were mobilized, and their investments in RES were not only motivated by the greatest available return, but also by the additional benefits described in the previous chapter. Thus, it was not until the market effect of the rapid growth of RES electricity became significant in

tricity-intensive companies would have to pay the full EEG apportionment from $1 \mathrm{~J}$ anuary 2015" (own translation, the author has a copy of this letter). In a similar vein, Rainer Baake, state secretary in the Federal Ministry of Economic Affairs and Energy, argued in an e-mailed letter to the representatives of the German Länder (states), why he was forced to reject almost all of the 70 proposals for amendments: "Many of the applications for amendments, however, lead to risks for notification because they deviate from the EC state aid guidelines" (own translation, the author has a copy of the letter). 
terms of low wholesale prices, that the traditional energy actors changed their strategy in particular their communication with regard to renewable energies (Kungl 2014: 25). Instead of criticizing RES as such, they introduced another problem framing to the debate and started "criticizing the difficulty of integrating them into the market, to the extent of claiming that they would pose a serious threat for the security of supply" (ibid.).

This problem framing of the need for market integration of renewable energies became the dominant framing in political debates - not only at the European level but also at the domestic level in Germany. ${ }^{21}$ Mandatory direct marketing, combined with a competitive auction scheme to determine the price for the market premium, is perceived by both the EC and the German government as the appropriate solution for this problem framing.

However, this instrumental shift is perceived by many stakeholders as a serious threat for a further engagement of those new actors who had driven the transition thus far. From the stakeholder's consultation regarding the redesign of the EEG ${ }^{22}$ and studies on the performance of different design options for RES support schemes (ecofys 2014, IZES 2014, AEE 2014) one can derive the following risks, which are assumed to affect the actor constellation in the energy field:

- Higher transaction cost for investors for taking part in auctioning

- Higher risks for investors

- Exclusion of smaller players - due to limited affordability of costs/ risks for cooperatives and private actors

- Threat for the process of de-centralization of the energy system through spatial concentration of generation facilities

- Exclusion of less mature RES-technologies

Furthermore, due to the practical experiences of other countries, the effectiveness in terms of low rates of project-implementation and the ostensibly cost-minimizing effect of auction schemes is also in question (ecofys 2014, IZES 2014).

This is not the place to discuss these risks in detail; however, they must be seriously taken into account when conceptualizing the precise design features of the instrument in Germany. As stakeholders are aware, that these design features - which so far are unspecified

${ }^{21}$ Various scientists have pointed to the shortcoming of this problem framing. They distinguish between the market integration and system integration of RES. They also make the point that, due to the volatile nature of RES, they will never fit with the current market design based on marginal cost. The scientists made several proposals for an adequate adaptation of the market design to be compatible with an increased share of volatile renewable energy sources (see for example Hauser and Zipp 2013, IZES et al. 2013).

22 The stakeholder's written statements are published at the Web-page oft the Federal Ministry for Economic Affairs and Energy: http:// www.bmwi.de/ DE/Themen/ Energie/ Erneuerbare-Energien/ EEGReform/stellungnahmen-zweite-runde.html . 
- crucially matter. The scientific and interest groups' struggle over the issue has only just begun.

In order to maintain public acceptance, maintain the citizens' and regional actors' engagement, and thus maintain the chances for a energy transition based on de-centralized energy system architecture, it is necessary to optimize the instrument's design with regard to its effectiveness, efficiency as well as to a symmetric distribution or reduction of both transaction costs and investment risks. Learning lessons from abroad might be the best available governance option at the moment, as practical experiences provide insights how to minimize the perceived risks. There are a few experiences available, for example that of Denmark, which demonstrate how to further ensure new actors' and local communities' engagement by introducing: location-specific tenders; the provision of information on local resource conditions before the submission of a tender, which allows more equal condition to all potential bidders; and by introducing participatory elements with a mandatory local resident participation in the projects (ecofys 2014: 61 pp.). Thus, such provisions introduce normative elements into a market design, which are underpinned by strategic policy decisions of the Danish government about how to transform the energy system.

The German government has publicly declared it will consider the contribution of the new actors to the previous success story of RES in Germany and not threaten the subnational efforts towards a low-carbon energy transition. It will be judged on this declaration by the future public acceptance of the energy transition, which so far has formed the crucial backbone of the entire undertaking. Whether this statement is more than mere lip service depends on the political will of the government to include such normative considerations into the design of the future national auction scheme.

\section{Conclusion}

The European Energy and Climate policy is at a crossroad. Indeed, so is the German energy transition process. As the country with the most ambitious approach to transforming a conventional-fuel-based energy system into a system based on renewable energy sources, Germany's domestic developments are of global importance. Stakeholders all over the world will recognize domestic policy shifts of such a fundamental dimension, especially their impact on further progress.

The paper has argued that the shift at the domestic level cannot merely be traced back to domestic struggles over meanings, policy goals and instrument choices. In fact, there was a clear need to adapt the EEG to the new requirements imposed by the increasing share of RES in electricity consumption and to introduce certain elements of cost and volume control into the scheme.

However, a prominent push for this kind of instrumental shift in the support scheme for RES came from the supranational level. The EC framed both the need for changes in the Community's target architecture as well as the necessity of adjusting national schemes to internal market requirements in a manner that indicates a confluence with the interests of 
powerful incumbent actors in the energy system. Additionally, the EC, as the supranational actor, creatively changed the rules of the game in an on-going European governance dilemma by using its discretionary power in the Union's competition law to force a shift in in instrument choices of national RES support schemes.

A transition towards a low-carbon society will be a process, one which is characterized by competing values, perceptions and goals of different actors, and by uncertainty and an ambiguity of scientific recommendations. However, founding political decisions on sustainable energy transition issues on one ideological component - that of single market functioning - will not be sufficient to achieve the other societal objectives, which so far have motivated and legitimized respective undertakings at several levels by numerous actors.

From the author's political science perspective, it will not be enough for EU Member States to claim their constitutional right to nationally decide on national energy matters. It will equally be insufficient to argue for the necessity of domestic solutions, which are more adaptive to the various national circumstances. Even a reference to regulatory competition between de-central policy jurisdictions to stimulate policy innovation might not be sufficient to change the dominant prism through which supranational actors currently look at energy transition matters.

Instead, to provide the necessary evidence for other founding principles of energypolicymaking beyond short-term cost-efficiency concerns, governmental actors should rely much more on the power from the bottom than they have in the past. At the subnational level, another paradigm of a low-carbon society is emerging. This alternate paradigm is gaining ideational power as well as economic relevance across societies in Europe. 


\section{Literature}

AEE (Agentur für Erneuerbare Energien) (2014): Studienvergleich: Finanzierungsinstrumente für Strom aus Erneuerbaren Energien. Metaanalyse von Vorschlägen für die zukünftige Finanzierung von Strom aus Erneuerbaren Energien. AEE. Berlin.

Ancygier, Andrzej and Kacper Szulecki (2013): Energia lokalna - czyli odnawialna? Raport z badania akceptacji dla odnawialnych źródet energii i perspektywy dla ich rozwoju w polskich gminach. In: ESPRI Report No 1. Environmental Studies and Policy Research Institute Wrocław.

Ancygier, Andrzej and Kacper Szulecki (2014): A Common Renewable Energy Policy in Europe? Explaining the German-Polish Policy Non-Convergence. In: ESPRI Working Paper No. 4. Environmental Studies and Policy Research Institute Wroctaw.

Bechberger, Mischa, Körner, Stefan, Reiche, Danyel (2003): Erfolgsbedingungen von Instrumenten zu Förderung zur Förderung erneuerbarer Energien im Strommarkt. FFUReport 03-2003, Berlin. Forschungszentrum für Umweltpolitik, FU Berlin.

Bulkeley, Harriet, and Kristine Kern (2009): Cities, Europeanization and Multi-Level Governance: Governing Climate Change Through Transnational Municipal Networks. In: J ournal of Common Market Studies 47(2): 309-332.

Busch, Per-Olof (2005). Institutionalisierter Politiktransfer mit Nebenwirkungen: Die Diffusion von Quoten und Einspeisevergütungen. In: Tews, K., and M. Jänicke [eds.]: Die Diffusion umweltpolitischer Innovationen im internationalen System, pp. 233-255.

Böckers, Veit, Haucap, Justus und Ulrich Heimeshoff (2013), Cost of Non-Europe in the Single Market for Energy. Benefits of an Integrated European Electricity Market: The Role of Competition, Bericht für das Europäische Parlament, J uni 2013. Study at the request of the European Added Value Unit, of the Directorate for Impact Assessment and European Added Value, within the Directorate General for Internal Policies (DG IPOL) of the General Secretariat of the European Parliament, available at: http:/ / www. europarl. europa. eu/ RegData/ etudes/ etudes/ join/ 2013/ 504466/ IPOLOIN ET\%282013\%29504466\%28ANN04\%29 EN.pdf.

Börzel, Tanja A. (2005). Mind the Gap! European Integration between level and scope. J ournal of European Public Policy 12(2): 217-236.

Börzel, Tanja A. 1999: Institutional Adaptation to Europeanization in Germany and Spain. In: J ournal of Common Market Studies 37:4, 573-596.

CEP (2014): Entwurf der Leitlinien der Europäischen Kommission für staatliche Umweltund Energiebeihilfen 2014-2020 J uristische und ökonomische Bewertung der Prüfkriterien zur Förderung erneuerbarer Energien. Centrum für Europäische Politik. Freiburg.

Dalhammar, Carl (2007): An Emerging Product Approach in Environmental Law. Incorporating the life cycle perspective. IIIEE Dissertations 2007: 3. Lund University.

Ecofys (2014): Design features of support schemes for renewable electricity. A report compiled within the European project "Cooperation between EU MS under the Renewable Energy Directive and interaction with support schemes". Study by order of European Commission, DG ENER. Utrecht.

European Commission (1998): Electricity from renewable energy sources and the internal electricity market. Brussels.

European Commission (2013a): Green Paper. A 2030 framework for climate and energy policies. COM(2013) 169 final. Brussels, 27.3.2013. 
European Commission (2013b): Flash Eurobarometer 360: ATTITUDES OF EUROPEANS TOWARDS AIR QUALITY. Conducted by TNS Political \& Social at the request of the European Commission, DG Environment. Brussels.

European Comission (2014a): Commission staff working document. Executive summary of the impact assessment accompanying the document Communication from the Commission to the European Parliament, the Council, the European Economic and Social Committee and the Committee of the Regions A policy framework for climate and energy in the period from 2020 up to 2030, SWD (2014) 016 final, EC, Brussels.

European Commission (2014b): Communication from the Commission to the European Parliament, the Council, the European Economic and Social Committee and the Committee of the Regions. A policy framework for climate and energy in the period from 2020 to 2030. COM(2014) 15 final. Brussels, 22.1.2014.

European Commission (2014c): Communication from the Commission to the European Parliament, the Council, the European Economic and Social Committee and the Committee of the Regions. Energy Efficiency and its contribution to energy security and the 2030 Framework for climate and energy policy. COM(2014) 520 final. Brussels, 23. 7. 2014.

European Commission (2014d) Communication from the Commission: Guidelines on State aid for environmental protection and energy 2014-2020. 2014/ C 200/ 01, Brussels.

Fischer, Severin and Oliver Geden 2011: Die deutsche Energiewende europäisch denken. In: SWP Aktuell Nr. 47. Stiftung Wissenschaft und Politik, Berlin.

Fischer, Severin and Kirsten Westphal (2012). Erneuerbare Energien im Stromsektor: Gestaltungsoptionen in der EU. SWP-Studie 27/2012. Stiftung Wissenschaft und Politik: Berlin.

FÖS (2014): Industrieausnahmen: Branchenliste schafft kaum Eingrenzung. Anspruch verschiedener Branchen auf EEG-Ausnahmen im Rahmen der EEG-Novelle 2014. Studie im Auftrag von Bündnis 90/ Die Grünen. Bearbeitet von Swantje Küchler unter Mitarbeit von Thomas Noppen. FÖS. Berlin

Gawel, Erik, Strunz, Sebastian und Paul Lehmann (2014): Wie viel Europa braucht die Energiewende? UFZ Discussion Paper. Department of Economics 4/ 2014. Helmholtz Centre for Environmental Research- UFZ. Leipzig.

Geden, Oliver and Severin Fischer (2014). Moving Targets. Die Verhandlungen über die Energie- und Klimapolitik-Ziele der EU nach 2020. SWP-Studie 1/2014. Stiftung Wissenschaft und Politik: Berlin.

Geels, Frank W. (2010): Ontologies, socio-technical transitions (to sustainability), and the multi-level perspective. In: Research Policy 39: 495-510.

Hakelberg, Lukas (2014): Governance by Diffusion: Transnational Municipal Networks and the Spread of Local Climate Strategies in Europe. In: Global Environmental Politics 14(1): 107-129:

Hartlapp, Miriam and Michael W. Bauer (2011): Determinanten der Konfliktgenese bei der Durchführung europäischer Politik. In: PVS 52(1): 3-28.

Hübner, Malte, Schmidt, Christoph. and Benjamin Weigert (2012): Energiepolitik: Erfolgreiche Energiewende nur im europäischen Kontext. Perspektiven der Wirtschaftspolitik 13(4): 286-307.

Haucap, Justus and Jürgen Kühling 2013: Zeit für eine grundlegende Reform der EEGFörderung - das Quotenmodell. Energiewirtschaftliche Tagesfragen 63 (3): 41-49. 
Hauser, Eva und Alexander Zipp (2013): Herausforderungen bei der Allokation von Strom ausfluktuierenden erneuerbaren Energien: Probleme und mögliche Lösungskonzepte. In: Vierteljahreshefte zur Wirtschaftsforschung 82(3): 155-169.

Heritier, Adrienne, Knill, Christoph and Susanne Mingers (1996). Ringing the Changes in Europe. Regulatory Competition and Redefinition of the State. Britain, France and Germany. Berlin: Walter de Gruyter.

IZES, Bofinger, BET (2013): Stromsystem-Design: Das EEG 2.0 und Eckpfeiler eines zukünftigen Regenerativwirtschaftsgesetzes. Endbericht. Studie im Auftrag der BadenWürttemberg Stiftung gGmbH. Saarbrücken, Würzburg, Aachen.

IZES (2014): Bewertung von Ausschreibungsverfahren als Finanzierungsmodell für Anlagen erneuerbarer Energienutzung. Endbericht für den Bundesverband Erneuerbare Energie e. V: . Saarbrücken.

Hey, Christian (2012): Low-carbon and energy strategies for the EU. The European Commission's Roadmaps: A Sound Agenda for Green Economy? In: GAIA 21/ 1: 43-47.

Hildingsson, Roger, Stripple, Johannes and Andrew Jordan (2011): Governing renewable energy in the EU: confronting a governance dilemma. In: European Political Science 11: $18-30$.

Holzinger, Katharina and Christoph Knill (2004). Competition and cooperation in environmental policy: individual and interaction effects. Journal of Public Policy, 24(1), 2547.

Jacob, Klaus et. al. (2010): Environment and the Single Market. Final Report to the European Commission, by Freie Universitaet Berlin, Adelphi Research, University of Konstanz, GHK, PSI and UCL Energy Institute. Available at: http:/ / ec. europa. eu/ environment/ enveco/ economics policy/ pdf/single market. pdf

Jacobs, David (2012). Renewable Energy Policy Convergence in the EU: The Evolution of Feedin Tariffs in Germany, Spain and France. London: Ashgate.

Jordan, Andrew, Huitema, Dave, van Asselt, Harro, Rayner, Tim and Frans Berkhout (2010): Climate Change Policy in the European Union: Confronting the Dilemmas of Adaptation and Mitigation? Cambridge: Cambridge University Press.

Kern, Kristine (2000): Die Diffusion von Politikinnovationen. Umweltpolitische Innovationen im Mehrebenensystem der USA. Opladen. Leske+Budrich.

Kitzing, Lena, Mitchell, Catherine an Poul Erik Morthorst (2012). Renewable energy policies in Europe: converging or diverging? Energy Policy 51: 192-201.

Knill, Christoph (1998). European Policies: The Impact of National Administrative Traditions. J ournal of Public Policy, 18(1), 1-28.

Kungl, Gregor (2014): The incumbent German power companies in a changing environment. A comparison of E. ON, RWE, EnBW an Vattenfall from 1998-2013. SOI Discussion Paper 2014-03. Research contributions to organizational sociology and innovation studies. University of Stuttgart.

Lauber, Volkmar and Elisa Schenner (2011): The struggle over support schemes for renewable electricity in the European Union: a discursive-institutionalist analysis. In: Environmental Politics 20(4): 508-527.

Lehmann, Paul und Erik Gawel (2013): Why should support schemes for renewable electricity complement the EU emissions trading scheme? Energy Policy 52, p. 597-607.

Leuffen, Dirk Rittberger, Berthold and Frank Schimmelfennig (2013). Differentiated Integration. Explaining Variation in the European Union. Basingstoke: Palgrave Macmillan. 
Macrory, Richard [ed.] (2006): Reflections on 30 Years of EU environmental law. A high level of protection? Proceedings of the Avosetta Group of European Environmental Laywers. European Law Publishing. Groningen.

Matthes, Felix C. (2010): Der Instrumenten-Mix einer ambitionierten Klimapolitik im Spannungsfeld von Emissionshandel und anderen Instrumenten. Bericht für das Bundesministerium für Umwelt, Naturschutz und Reaktorsicherheit. Berlin, Darmstadt, Freiburg: Öko-Institut e.V.

McGowan, Lee and Stephen Wilks (1995): The first supranational policy in the European Union: Competition Policy. In: European J ournal of Political Research 28: 141-169.

Michniowsi, Zbigniew (2014): Poland's other energy story: taking a closer look. In: EurActiv.com, 18.06.2014. http:// www. euractiv. com/ sections/ energy/ polandsother-energy-story-taking-closer-look-302897.

Morris, Craig (2014): Get this: Germany does not have generous subsidies for renewables. In: energypost.eu, 16.07.2014. http:// www.energypost. eu/get-germany-generoussubsidies-renewables/.

Oates, W. E. (1998). Environmental Policy in the European Community: Harmonization or National Standards? In: Empirica 25: 1-13.

Ohlhorst, Dörte, Tews, Kerstin und Miranda Schreurs (2013): Energiewende als Herausforderung der Koordination im Mehrebenensystem. In: Technikfolgenabschätzung. Theorie und Praxis, 22(2): 48-55.

Pagh, Peter (2006): Challenging the stricter approach: Stricter might lead to weaker protection. In: Macrory, R. [ed.], Reflections on 30 Years of EU Environmental Law. A High Level of Protection? Europe Law Publishing, Groningen, pp. 3-16.

Radaelli, Claudio M. 2003: The Europeanization of Public Policy. In: Kevin Featherstone, Kevin/ Radaelli, Claudio M. (eds.): The Politics of Europeanization. Oxford: Oxford University Press, 27-56.

Rave, Tilmann, Triebswetter, Ursula and J ohann Wackerbauer (2013): Koordination von Innovations-, Energie- und Umweltpolitik. In: Expertenkommission Forschung und Innovation (EFI) [ed.]: Studien zum deutschen Innovationssystem Nr. 10-2013, Berlin.

Scharpf, Fritz (1996): Politische Optionen im vollendeten Binnenmarkt. In: J achtenfuchs, M. and B. Kohler-Koch [eds.] (1996): pp. 109-140.

Schimmelfennig, Frank, and Berthold Rittberger. 2006. Theories of European Integration: Assumptions and Hypotheses. In: Richardson, Jeremy [ed.], European Union: Power and Policy-Making. pp. 73-96. London: Routledge.

Schreurs, Miranda A. (2013): Orchestrating a Low-Carbon Energy Revolution Without Nuclear: Germany's Response to the Fukushima Nuclear Crisis. In: Theoretical Inquiries in Law 14(1): 83-104.

Steuwer, Sibyl D. (2013): Energy Efficiency governance. The case of white certificate instruments for energy efficiency in Europe. Sringer VS. Wiesbaden.

Steuwer, Sibyl D. (2014): Implementation of the European Energy Efficiency Directive. Towards a strategic approach in energy efficiency governance? Unpublished manuscript. forthcoming in: FFU-Report. Berlin.

Strunz, Sebastian, Gawel, Erik and Paul Lehmann (2014a): Towards a general "Europeanization" of EU Member States' energy policies? In: UFZ Discussion Paper. Department of Economics 17/ 2014. Helmholtz Centre for Environmental Research- UFZ. Leipzig 
Strunz, Sebastian, Gawel, Erik and Paul Lehmann (2014b): On the alleged need to strictly "Europeanize" the German Energiewende. In: UFZ Discussion Paper. Department of Economics 18/ 2014. Helmholtz Centre for Environmental Research- UFZ. Leipzig

Tews, Kerstin (2005): The Diffusion of Environmental Policy Innovations: Cornerstones of an Analytical Framework. In: European Environment 15(2): 63-79.

Tews, Kerstin and Martin Jänicke [eds.] (2005): Die Diffusion umweltpolitischer Innovationen im internationalen System. Wiesbaden: VS - Verlag für Sozialwissenschaften.

Tews, Kerstin (2006): The diffusion of environmental policy innovations. In: Winter, Gerd [ed.], Multilevel Governance for Global Environmental Change. Perspectives from Science, Sociology and the Law, pp. 227-253. Cambridge University Press. Cambridge.

Tews, Kerstin, Busch, Per-Olof and Helge J örgens (2003): The Diffusion of New Environmental Policy Instruments. In: European J ournal of Political Research 42(4): 569-600.

Tews, Kerstin and Hendrik Vagt (2010): Single market regulation and environmental policy. The legal perspective. In: J acob et al., Environment and the Single Market. Final Report to the European Commission, pp. 46-61

Torre-Schaub, Martha (2006): The single market and the environment: Pathways to integration. Global Law Working Papers 05/ 2006.

trend:research GmbH and Leuphana Universität Lüneburg (2013): Definition und Marktanalyse von Bürgerenergie in Deutschland. Study carried out on behalf of the Initiative "Die Wende - Energie in Bürgerhand" and the "Agentur für Erneuerbare Energien". Bremen/ Lüneburg.

Weale, Albert, Pridham Geoffrey, Cini, Michelle, Konstadakopulo, Dimitrios, Porter, Martin and Brendan Flynn (2000): Environmental Governance in Europe. Oxford: Oxford University Press.

Westphal, Kirsten (2012): Globalising the German Energy Transition. SWP Comments 40. Stiftung Wissenschaft und Politik. Berlin.

Wettestad, J ørgen, Eikeland, Per Ove and Måns Nilsson (2012): EU Climate and Energy Policy: A Hesitant Supranational Turn? In: Global Environmental Politics 12(2): 67-86. 